\title{
Pseudomonas maltophilia, an Alcaligenes-like Species
}

\author{
By R. HUGH AND EWDOKIA RYSCHENKOW \\ Department of Microbiology and Community Health, The George Washington \\ University School of Medicine, Washington, D.C., U.S.A.
}

(Received 28 February 1961)

\begin{abstract}
SUMMARY
Pseudomonas maltophilia is frequently encountered in specimens submitted to the clinical laboratory for bacteriological examination. This report describes morphological, physiological and serological attributes of this species. Photomicrographs show the presence of polar multitrichous flagella in stained preparations. These pseudomonads do not produce acid from glucose but readily produce acidity from maltose oxidation. A historical review of the epithet Alcaligenes bookeri is presented.
\end{abstract}

\section{INTRODUCTION}

'Bacterium bookeri' NCTC 6572 was isolated in 1943 by J. L. Edwards (Public Health Department, County Bacteriology Laboratory, Stafford, England) from a specimen of pleural fluid and was reported as being non-motile and probably a skin contaminant. It was later found (Hugh, 1953) to have multitrichous flagella. Hugh (1953) recorded the morphological and physiological characteristics of six strains that are now classified as $\boldsymbol{P}$ seudomonas maltophilia including NCTC strain 6572, in a study of Alcaligenes. It became apparent that $\boldsymbol{P}$. maltophilia had been unwittingly misidentified as Alcaligenes faecalis by Ulrich \& Needham (1953); see their strains 249 and 282. An additional 28 strains of $\boldsymbol{P}$. maltophilia have since been isolated from the following sources : river water, well water, raw milk, frozen fish, rabbit and human faeces, blood, pericardial fluid, ascitic fluid, pleural fluid, spinal fluid, oropharyngeal swabs, and contaminated tissue culture. Twenty-six of the above strains have now been restudied and the detailed results are recorded here. An abstract (Hugh \& Ryschenkow, 1960) has already been published. The present report serves to amend the previously published description; the name dates from May, 1960 and should be cited as Pseudomonas maltophilia Hugh \& Ryschenkow, 1960.

\section{METHODS}

Morphology. Leifson's (1960) technique was employed to stain flagella.

Physiology. The effects of the bacteria on carbohydrates were determined by the OF (oxidative-fermentative) principle of Hugh \& Leifson (1953) and Leifson (1958). The medium used had the following composition: Difco Casitone (pancreatic digest of casein), $5 \mathrm{~g}$.; agar, $3 \mathrm{~g}$.; bromthymol blue ( $2 \%$, w/v, aqueous solution), $4 \mathrm{ml}$.; carbohydrate, $10 \mathrm{~g}$.; distilled water, $1000 \mathrm{ml}$; f final $\mathrm{pH} 7 \cdot 1$.

Seitz-filtered $10 \%(\mathrm{w} / \mathrm{v})$ carbohydrate solution was added aseptically to the cool autoclaved $\left(15 \mathrm{~min}\right.$. at $\left.121^{\circ}\right)$ melted basal medium. The medium was then dispensed 
aseptically into $13 \times 100 \mathrm{~mm}$. sterile tubes to a depth of $50 \mathrm{~mm}$. Ethanol medium was prepared by adding $3 \mathrm{ml}$. Seitz-filtered absolute ethanol to $97 \mathrm{ml}$. of the above melted OF basal medium. The ethanol medium was dispensed into sterile $13 \times 100 \mathrm{~mm}$. tubes to a depth of $50 \mathrm{~mm}$. and immediately cooled. Ability to grow in an acid medium was studied in yeast extract broth adjusted to $\mathrm{pH} 4.5$ with $\mathrm{HCl}$ (Rhodes, 1959) as described by Shimwell, Carr \& Rhodes (1960).

Modified Kovacs's reagent (Gadebusch \& Gabriel, 1956) was used to detect indole in $1 \%(\mathrm{w} / \mathrm{v})$ tryptone broth. Simmons's citrate, Christensen's urea, Møller's (1954, 1955) KCN broth, Kligler's iron agar for hydrogen sulphide detection, Kohn's (1953) charcoal gelatin, Carlquist's (1956) test for lysine decarboxylase activity, phenylalanine deaminase activity (Ewing, Davis \& Reaves, 1957), the cytochrome oxidase slope test of Ewing \& Johnson (1960), and the 2-ketogluconate test of Moore \& Pickett (1960) were used. Physiological tests were incubated at $37^{\circ}$; time of incubation and criteria for the tests being positive are given in the references cited and are described by Ewing (1960).

\section{Serology}

Preparation of antigen for production of $\boldsymbol{O}$ antisera. Brain heart infusion broth cultures, incubated at $37^{\circ}$ for $24 \mathrm{hr}$., were placed in flowing steam $\left(100^{\circ}\right)$ for $2 \mathrm{hr}$. and preserved by adding $0.3 \mathrm{ml}$. of commercial $40 \%(\mathrm{w} / \mathrm{v})$ formaldehyde to $100 \mathrm{ml}$. of the broth.

Preparation of antigen for production of $\boldsymbol{H}$ antisera. Actively motile organisms, picked from spreading growth in semi-solid agar Gard (1938) plate incubated at room temperature, were inoculated into brain heart infusion broth. After incubation at $22^{\circ}$ for $18-24 \mathrm{hr}$, the broth was diluted with an equal volume of saline containing $0 \cdot 6 \%(\mathrm{v} / \mathrm{v})$ formalin.

Schedule of immunization. Rabbits were given four intravenous injections of $\mathbf{H}$ or $O$ antigen at intervals of 4 days. The volume administered was increased each time as follows: $0.5,1.0,2.0$ and $4.0 \mathrm{ml}$. The animals were bled on the sixth day after the last injection. Normal serum for control was obtained from each rabbit before immunization. The sera were preserved by the addition of an equal volume of glycerol and stored at $4^{\circ}$.

Preparation of antigens for $\mathrm{O}$ and $\mathrm{H}$ agglutination. Antigen for $\mathrm{O}$ slide-agglutination tests was prepared from an infusion agar slope incubated at $37^{\circ}$ for $24 \mathrm{hr}$. The growth was emulsified in $0.5 \mathrm{ml}$. saline to form a dense homogeneous suspension. The suspensions were placed in a boiling water bath for $15 \mathrm{~min}$., cooled and tested. Antigen for $\mathbf{H}$ tube agglutinations was prepared in the same manner as antigen used for the production of $\mathbf{H}$ antisera.

Serological technique. The somatic agglutination of an organism was determined by slide agglutination with a $1 / 10$ dilution of the $\mathrm{O}$ antisera. The technique described by Edwards \& Ewing (1955) for the somatic agglutination of salmonellas was followed. A twelve tube serial dilution of $\mathbf{H}$ antiserum was used to determine flagellar agglutination of the organisms. Tubes were examined for flocculent agglutination after incubation at $45^{\circ}$ for $1 \mathrm{hr}$. followed by $18 \mathrm{hr}$. at $10^{\circ}$. 


\section{RESULTS}

Morphology

The organism in peptone broth was a Gram-negative rod about $0.5 \times 1.5 \mu$. Capsule and spore formation was not demonstrable. All the strains were motile and showed a tuft of polar flagella. Plate 1 illustrates the polar multitrichous morphology of Pseudomonas maltophilia. The flagella appear to be similar in wavelength and amplitude to the flagella of a typical strain of $P$. aeruginosa.

\section{Physiology}

This strictly aerobic organism produced a dense turbidity in peptone broth in 18-24 hr. The strains studied did not produce a distinctive pigment in ordinary media. Smooth glistening growth with an entire margin readily appeared on nutrient agar and blood agar in $24 \mathrm{hr}$. at $37^{\circ}$. All strains produced grey to white colonies on Leifson's deoxycholate agar. A few strains required $48 \mathrm{hr}$. to grow out on this medium. Sheep erythrocytes in infusion agar base around well-isolated surface colonies of all 26 strains were not haemolysed. The tube haemolysis test with sheep erythrocytes, as performed in the study of cholera vibrios (Pollitzer, 1959), was negative for all strains. None of the strains grew in peptone broth at $\mathrm{pH} 4.5$.

The following physiological reactions were negative for all 26 strains : acidity from arabinose, glucose, galactose, lactose, mannitol, rhamnose, sucrose, xylose; the indole, methyl red, and Voges-Proskauer tests; urea hydrolysis, nitrate conversion to nitrogen gas, hydrogen sulphide production, phenylalanine deaminase, and 2-ketogluconate production.

The following physiological reactions were positive for all 26 strains : acidity from maltose (acidity was produced in the open tube, but not in the closed tube), motility, gelatin, catalase and lysine decarboxylase. The gelatin test generally became positive before the fourth day. Acidity from maltose generally became evident on the first or second day. Freshly isolated strains of Pseudomonas maltophilia inoculated into the basal medium and basal medium containing glucose or other carbohydrates which were not metabolized, produced a strong alkaline reaction at the surface of the medium after 24-48 hr. of incubation. Some old strains which have been kept alive in the laboratory for 8-10 years by periodical transfer in semisolid medium now produce a very weak acid reaction after prolonged incubation in glucose medium. Some strains produced a positive reaction, while others produced a negative reaction in the tests listed in Table 1.

\section{Antigenic structure}

$O$ antigens. Fifteen distinct somatic serotypes were encountered among the 26 strains of Pseudomonas maltophilia (Table 2). Organisms of one somatic serotype did not appear to share major antigens with organisms of other serotypes, since cross-reactions between the various $\mathbf{O}$ groups were not pronounced. Slow and weak minimal agglutination reactions, which occurred infrequently, were interpreted to be due to minor antigens and were recorded as negative $(-)$ in Table 2 . The serum with which the antigen first reacted established the $\mathbf{O}$ group to which the organism was assigned. These positive $(+)$ reactions were prompt and strong. 
Table 1. Physiological variability found in 26 Pseudomonas maltophilia strains

\begin{tabular}{|c|c|c|c|}
\hline & \multicolumn{2}{|c|}{ Number of strains } & \multirow{2}{*}{$\begin{array}{l}\text { Time required for the strains } \\
\text { to become positive at } 37^{\circ}\end{array}$} \\
\hline & Positive & Negative & \\
\hline Acidity from fructose (aerobic) & 3 & $\mathbf{2 3}$ & $\begin{array}{l}\text { Positive on the 1st day, after } \\
\text { 2nd day positives began to } \\
\text { become alkaline }\end{array}$ \\
\hline Acidity from mannose (aerobic) & 23 & $\mathbf{3}$ & $\begin{array}{l}\text { Generally positive on the 1st } \\
\text { or 2nd day }\end{array}$ \\
\hline Citrate utilization & 6 & 20 & Generally positive on 2 nd day \\
\hline $\mathrm{KCN}$ resistance & 23 & $\mathbf{3}$ & Positive on 1st or 2nd day \\
\hline Nitrate reduction to nitrite & 11 & 15 & $\begin{array}{l}\text { Test performed after } 48 \mathrm{hr} \text {. } \\
\text { incubation }\end{array}$ \\
\hline $\begin{array}{l}\text { Cytochrome oxidase } \\
\text { slope test }\end{array}$ & 16 & 10 & $\begin{array}{l}\text { Test performed after } 24 \mathrm{hr} \text {. } \\
\text { incubation }\end{array}$ \\
\hline Acidity from ethanol (aerobic) & 1 & 25 & 4 days \\
\hline
\end{tabular}

Living suspensions of Pseudomonas maltophilia and suspensions treated with ethanol and heat were also used in the $\mathbf{O}$ slide-agglutination test. Of the three different $O$ antigen preparations tested, the boiled suspensions were most suitable. The ethanol treated suspensions and the living suspensions frequently produced a slow and weak agglutination, or no agglutination, with homologous antisera. The information recorded in Table 2 was obtained with boiled suspensions of $\boldsymbol{P}$. maltophilia. Undiluted glycerol-preserved normal control serum did not agglutinate the corresponding organism used for immunization.

Table 2. $O$ agglutination of Pseudomonas maltophilia with antisera prepared against the corresponding organism

\begin{tabular}{|c|c|c|c|c|c|c|c|c|c|c|c|c|c|c|c|}
\hline \multirow[t]{2}{*}{ Antigen } & \multicolumn{15}{|c|}{ Antiserum } \\
\hline & \& & $\underset{\infty}{\mathbb{1}}$ & 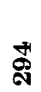 & 10 & 8 & $\overline{8}$ & 20 & $\frac{7}{7}$ & 象 & (7) & $\begin{array}{l}p \\
\infty \\
\infty \\
\infty\end{array}$ & 苫 & $\underset{0}{\stackrel{7}{0}}$ & गें & $\stackrel{p}{\infty}$ \\
\hline $560,430,559,661-1$ & + & - & - & - & - & - & - & - & - & - & - & - & - & - & - \\
\hline $810-2,104-2,245-3$ & - & + & - & - & - & - & - & - & - & - & - & - & - & - & - \\
\hline 294 & - & - & + & - & - & - & - & - & - & - & - & - & - & - & - \\
\hline $\mathbf{5 5 5}$ & - & - & - & + & - & - & - & - & - & - & - & - & - & - & - \\
\hline $609,229,194-1,457-1$ & - & - & - & - & + & - & - & - & - & - & - & - & - & - & - \\
\hline 601,611 & - & - & - & - & - & + & - & - & - & - & - & - & - & - & - \\
\hline $557,751-4$ & - & - & - & - & - & - & + & - & - & - & - & - & - & - & - \\
\hline 447 & - & - & - & - & - & - & - & + & - & - & - & - & - & - & - \\
\hline $558,483-2$ & - & - & - & - & - & - & - & - & + & - & - & - & - & - & - \\
\hline $653-4$ & - & - & - & - & - & - & - & - & - & + & - & - & - & - & - \\
\hline $788-3$ & - & - & - & - & - & - & - & - & - & - & + & - & - & - & - \\
\hline 556 & - & - & - & - & - & - & - & - & - & - & - & + & - & - & - \\
\hline $109-4$ & - & - & - & - & - & - & - & - & - & - & - & - & + & - & 一 \\
\hline $363-4$ & - & - & - & - & - & - & - & - & - & - & - & - & - & + & - \\
\hline 873-3 & - & - & - & - & - & - & - & - & - & - & - & - & - & - & + \\
\hline
\end{tabular}

$+=$ strong agglutination reaction.

- = no agglutination or weak and slow agglutination.

The 15 Pseudomonas maltophilia $\mathrm{O}$ antisera did not agglutinate $\mathrm{O}$ antigens prepared from 2 strains of each of the following 8 organisms: Aeromonas hydrophila, Alcaligenes faecalis (peritrichous), Bordetella bronchiseptica, Herellia vaginicola, 
Lophomonas alcaligenes, Pseudomonas aeruginosa, Mima polymorpha, Pseudomonas diminuta. The $16 \mathrm{O}$ antigens of the above organisms were prepared in the same manner as were the $\boldsymbol{P}$. maltophilia $\mathrm{O}$ antigens.

There was no evidence of an $\mathrm{O}$ antigen common to the following three groups of Pseudomonas maltophilia: 12 strains of oropharyngeal origin, 5 strains which apparently were the cause of natural infections, and 2 strains of faecal origin.

Two of the $\mathbf{O}$ antigen groups were examined by absorption to confirm that the $O$ antigens within each were serologically similar. The homologous somatic antibodies in antiserum produced by immunization with a boiled suspension of strain 560 were removed by absorption with a live suspension of strain 430 or 559 (see Table 3). The homologous somatic antibodies in antiserum produced by immunization with a boiled suspension of strain 810-2 were removed by absorption with a live suspension of strain 104-2 or 245-3 (see Table 4).

Table 3. Agglutination following absorption of homologous $O$ antibodies to Pseudomonas maltophilia strain 560 with heterologous organisms

$\begin{array}{cccc}\begin{array}{c}\text { Living } \\ \text { suspension } \\ \text { (strain number) }\end{array} & \begin{array}{c}\text { Unabsorbed o } \\ \text { antiserum to } \\ \text { strain } 560\end{array} & \begin{array}{c}\mathbf{4 3 0} \\ \mathbf{5 6 0} \text { absorbed with strain }\end{array} \\ \mathbf{5 6 0} & + & - & \mathbf{5 5 9} \\ \mathbf{4 3 0} & + & - & - \\ \mathbf{5 5 9} & + & - & - \\ \mathbf{6 6 1 - 1} & + & - & -\end{array}$

Table 4. Agglutination following absorption of homologous $O$ antibodies to Pseudomonas maltophilia strain 810-2 with heterologous organisms

\begin{tabular}{|c|c|c|c|}
\hline \multirow{2}{*}{$\begin{array}{c}\text { Living } \\
\text { suspension } \\
\text { (strain number) }\end{array}$} & \multirow{2}{*}{$\begin{array}{l}\text { Unabsorbed } O \\
\text { antiserum to } \\
\text { strain 810-2 }\end{array}$} & \multicolumn{2}{|c|}{$\begin{array}{l}\text { O antiserum to strain } \\
\text { 810-2 absorbed with strain }\end{array}$} \\
\hline & & 104-2 & $245-3$ \\
\hline $810-2$ & + & - & - \\
\hline 104-2 & + & - & - \\
\hline 245-3 & + & - & - \\
\hline
\end{tabular}

$H$ antigens. The reciprocal of the homologous titres of each of the six $\mathrm{H}$ antisera are tabulated in Table 5. All 26 strains of Pseudomonas maltophilia were agglutinated by one or more of the six $\mathbf{H}$ antisera. The $\mathbf{H}$ antiserum prepared with $\boldsymbol{P}$. maltophilia strain 560 agglutinated 23 of the 26 strains (88\%). Eighteen of the strains $(69 \%)$ appear to have a very similar flagellar antigenic structure. There appear to be at least 4 distinct flagellar antigens.

Glycerol-preserved normal serum in dilutions of 1/20, 1/40 and 1/80 did not agglutinate the corresponding organisms used for immunization.

A fine granular agglutination reaction occurred in some of the $\mathrm{H}$ agglutination tests in antiserum dilutions of 1/80 or less. This was best seen with $\mathrm{a} \times 10$ hand lens. This phenomenon was interpreted to be due to $\mathbf{O}$ antibodies in the $\mathbf{H}$ antiserum reacting with the cell bodies of the formalinized flagellar antigen. Such reactions are recorded as negative $(-)$ in Table 5 . 
Table 5. Flagellar agglutination of Pseudomonas maltophilia strains with antisera prepared against the corresponding organism

\begin{tabular}{|c|c|c|c|c|c|c|}
\hline \multirow{3}{*}{$\begin{array}{l}\text { Suspension } \\
\text { (strain no.) }\end{array}$} & \multicolumn{6}{|c|}{ Antisera against strains } \\
\hline & 555 & 560 & $810-2$ & 104-2 & 294 & 557 \\
\hline & \multicolumn{6}{|c|}{ Reciprocal of dilutions } \\
\hline $\mathbf{5 5 5}$ & 20,480 & 10,240 & 2,560 & - & - & 一 \\
\hline 560 & 20,480 & 10,240 & 2,560 & - & 一 & - \\
\hline $447,556 *$ & 5,120 to 20,480 & 2,560 to 10,240 & 1,280 to 5,120 & - & 一 & - \\
\hline $810-2,245-3$ & 10,240 & 5,120 & 20,480 & 20,480 & - & - \\
\hline $104-2$ & - & - & 10,240 & 40,960 & - & 一 \\
\hline 294 & - & - & - & - & 5,120 & - \\
\hline 611 & 20,480 & 10,240 & 2,560 & 一 & 5,120 & 一 \\
\hline 229 & 20,480 & 2,560 & - & - & - & 一 \\
\hline 430 & - & 10,240 & - & - & - & - \\
\hline 557 & - & - & - & 一 & 一 & 10,240 \\
\hline
\end{tabular}

\section{DISCUSSION}

The 26 strains of Pseudomonas maltophilia examined were morphologically and biochemically much alike, but serologically highly diverse. The following characteristics generally serve to identify the species:

$\begin{array}{ll}\text { Flagellation } & \text { Polar multitrichous } \\ \text { Acid from glucose (aerobic) } & \text { No acid } \\ \text { Acid from maltose (aerobic) } & \text { Acid } \\ \text { Acid from maltose (anaerobic) } & \text { No acid } \\ \text { Acid from mannose (aerobic) } & \text { Acid } \\ \text { Citrate utilization } & \text { Negative } \\ \text { Potassium cyanide resistance } & \text { Positive } \\ \text { Nitrate reduced to nitrogen gas } & \text { No gas } \\ \text { Charcoal gelatin } & \text { Hydrolysed } \\ \text { Lysine decarboxylase (Carlquist) } & \text { Positive } \\ \text { 2-Ketogluconate production } & \text { Negative }\end{array}$

Although no haemolysis was seen around well-isolated colonies, blood agar medium around colonies in the heavily inoculated areas showed a greenish discoloration. This discoloration was interpreted to be the result of excessive accumulation of alkaline metabolic by-products.

The oxidase test for this species of Pseudomonas is often positive, delayed and generally difficult to interpret. The positive reactions, obtained with some strains of Pseudomonas maltophilia, are generally not as intense as those seen with cholera vibrios and Aeromonas. The value of the oxidase test as the sole criterion for the recognition of species of Pseudomonas has marked limitations since some species do not produce a positive test and Vibrio comma and aeromonads produce a positive test. On the basis of these observations it does not appear judicious to incorporate a positive oxidase test as part of the description of the genus Pseudomonas. 
The physiological variability found among the 26 strains of Pseudomonas maltophilia studied (see Table 1) is interpreted to be variation within the concept of species. No attempt was made to designate physiological varieties of the species in view of the limited number of strains studied and the apparent absence of a practical reason for such division.

Serological reactions did not serve the authors as a useful tool to screen unknown organisms in search of Pseudomonas maltophilia. Cursory studies on a strain of $P$. maltophilia might result in confusion with Alcaligenes faecalis, Bordetella bronchiseptica or Lophomonas alcaligenes, since all are motile and produce an alkaline reaction in glucose peptone broth. $A$. faecalis and $B$. bronchiseptica have peritrichous flagella. L. alcaligenes has lophotrichous flagella and does not attack carbohydrate, hence it differs from $\boldsymbol{P}$. maltophilia which has polar multitrichous flagella and oxidizes maltose and mannose. Clinical bacteriologists frequently fail to differentiate the above organisms because the identification is erroneously thought to be based on a single character or at most only a few characters, and often these are not necessarily the most important for recognition of the taxon. Before the identity of an aerobic, asporogenous Gram-negative, glucose-nonfermenting rod should be regarded as established, the complete morphological and physiological reaction pattern should be determined and compared with the complete pattern of the species in the genus. If the reaction patterns have not been suitably worked out the unknown organism must be compared with recognized authentic type or neotype cultures.

The authors recognize that other species of Pseudomonas might be closely related $\boldsymbol{P}$. maltophilia. However, it is difficult to state how other species are related or how they may be precisely differentiated at this stage of our understanding. Ninetyfour differently named species of Pseudomonas deposited in the American Type Culture Collection were studied; not one of the strains possessed the characteristics of $\boldsymbol{P}$. maltophilia.

Pseudomonas maltophilia 810-2 is designed the type strain. Strains 560, 611, 661-1 and 873-3 may also be useful in future comparative studies. These five strains have been placed in various repositories and have the following corresponding accession numbers:

$\begin{array}{ccc}\text { RH number } & \begin{array}{c}\text { Canadian National } \\ \text { Research Council } \\ \text { number }\end{array} & \begin{array}{c}\text { American Type } \\ \text { Culture Collection } \\ \text { number }\end{array} \\ 560 & - & 13636 \\ 611 & 727 & 13843 \\ 661-1 & 728 & - \\ 810-2 & 729 & 13637 \\ 873-3 & 730 & -\end{array}$

The species name Alcaligenes bookeri has been inadvertently assigned to strains included in the above described taxon; hence it would appear appropriate to review the history of this name. Booker (1887) isolated an organism from the faeces of children with diarrhoea. He labelled the organism Bacillus A and described it as actively motile; milk coagulated, alkaline and peptonized; gelatine liquefied. No mention was made of the Gram reaction, carbohydrate reaction or flagellation. Booker (1890) stated that his Bacillus A might have been Proteus vulgaris. Ford 
(1903) proposed the name 'Bacillus bookeri' for an organism he isolated from the intestine of a child and considered to be like Booker's Bacillus A. He described the organism as : rod shaped; no spores, no effect on glucose, lactose or sucrose; aerobic; yellow or yellow-brown growth on agar slope; litmus milk alkaline and reduced; nitrate to nitrite reduction negative; gelatin, casein and coagulated serum liquefied; indole not produced. There is no statement of Gram reaction or flagellar morphology in Ford's report. It does not seem to us that Ford's 'Bacillus bookeri' was adequately enough described to enable one to recognize the species today with certainty. Levine \& Soppeland (1926) proposed the name 'Bacterium bookeri'. Weldin (1927) and Kutscher (1937) did not describe the flagellar morphology of their strains of Alcaligenes bookeri. Subsequent literature reviews, such as Bergey's Manual (1923, 1957) also used the name $A$. bookeri. $A$. bookeri is described as an organism with the general properties of alcaligenes and specifically with peritrichous flagella and ability to liquefy gelatin; however, the source of this description has not been made evident. It is generally agreed that the type species Alcaligenes faecalis is a peritrichous organism. It follows that any other flagellated species included in the genus must also be peritrichous. In view of these comments we consider that $A$. bookeri is a species incertae sedis and therefore the epithet bookeri should not be applied to $\boldsymbol{P}$ seudomonas maltophilia. In addition, $\boldsymbol{P}$. maltophilia is a polar flagellated organism; hence it is not appropriate to place the taxon in the genus Alcaligenes. A review of the literature has not as yet been productive in establishing an earlier epithet for the taxon described in this report.

The specific epithet and noun maltophilia is derived from the old Anglo-Saxon word malt and the Greek work philia. It has the literal word meaning 'malt friend' or 'friend of malt'. The etymology of the specific epithet $\boldsymbol{P}$. maltophilia makes it clear that it is a hybrid epithet. This is a subsidiary point and does not affect the acceptance of the name.

The utilization by bacteria of disaccharides without utilization of either of its constituent monosaccharides has been observed repeatedly. Pelczar \& Doetsch (1949) described a Neisseria sp. which utilized maltose with acid production while glucose was not utilized. The authors can confirm the existence of such an unnamed Neisseria sp. in the oropharyngeal region. Pseudomonas maltophilia is yet another example of an organism with this type of physiology.

Liu (1961) concluded that identification of pseudomonads is difficult because of the lack of a biochemical reaction pattern for each species and that identification of species is dependent upon unstable pigment production and unstable pathogenicity. The observations presented in this study of Pseudomonas maltophilia do not offer support for these conclusions. The following redefinition of the genus Pseudomonas has been found useful: Gram-negative straight or curved rods, polar-flagellated when motile; strict aerobes which do not produce acid from glucose under anaerobic conditions in a glucose peptone medium, glucose may be oxidized to acid end products in the presence of oxygen; indole, methyl red and Voges-Proskauer tests negative; pigments when present are usually water soluble.

During the later stages of preparation of this manuscript in $1961 \mathrm{Dr} \mathrm{J}$. Tannenberg (Genessee Laboratory, Batavia, New York, U.S.A.) informed us that Pseudomonas maltophilia strain 1144, was isolated in pure culture at a necropsy from granulomatous lesions in the lung and heart musculature. Bacterial colonies appeared to be present 
within small granulomata at the boundary between necrosis and granulomatous cells. Strain 1144 was agglutinated by $O$ antiserum 560. Strains 560, 430, 559 and 661-1 were isolated from spinal fluid, human oviduct, chest fluid and buccal cavity of a normal adult, respectively. Dr J. Tannenberg will amplify these observations and prepare a report later.

This work was supported in part by research grant E-2819-A from the National Institutes of Health, Department of Health, Education, and Welfare, U.S. Public Health Service, U.S.A. and Grant 343 from the Committee on Research, Council on Pharmacy and Chemistry, American Medical Association. The authors are indebted to Elizabeth O. King of the Communicable Disease Center, Chamblee, Georgia, for 6 strains of Pseudomonas maltophilia which she identified.

One of the authors (R.H.) is deeply indebted to Professor E. Leifson, whose unfailing help, encouragement and advice made this study possible from the very onset, and to Professor R. E. Buchanan for offering assistance with the manuscript.

\section{REFERENCES}

Bergey's Manual of Determinative Bacteriology (1923). 1st ed., ed. D. H. Bergey. Baltimore: Williams and Wilkins.

Bergey's Manual of Determinative Bacteriology (1957). 7th ed., ed. by R. S. Breed, E. G. D. Murray \& N. R. Smith. Baltimore: Williams and Wilkins.

Booker, W. D. (1887). A study of some of the bacteria found in the dejecta of infants afflicted with summer diarrhoea. Trans. 9th int. Congr. Med. 3, 598.

Booker, W. D. (1890). A study of some of the bacteria found in the faeces of infants affected with summer diarrhoea. Arch. Pediat. 7, 92.

Carlquist, P. R. (1956). A biochemical test for separating Paracolon groups. J. Bact. 71, 339.

EDwards, P. R. \& Ewing, W. H. (1955). Identification of Enterobacteriaceae, p. 31. Minneapolis: Burgess Publishing Co.

Ewing, W. H. (1960). Enterobacteriaceae: Biochemical methods for group differentiation. P.H.S. publication No. 734. Washington, D.C.: U.S. Government Printing Office.

Ewing, W. H., Davis, B. R. \& Reavis, R. W. (1957). Phenylalanine and malonate media and their use in enteric bacteriology. Pub. Hlth Lab. (Burlington, Vermont), 15, 153.

Ewing, W. H. \& Johnson, J. G. (1960). The differentiation of Aeromonas and C27 cultures from Enterobacteriaceae. Int. Bull. bact. Nomencl. 10, 223.

Ford, W. W. (1903). The classification and distribution of the intestinal bacteria in man. Montreal Royal Victoria Hospital Studies, 1,1 (No. 5).

Gadebusch, H. H. \& Gabriel, S. (1956). Modified stable Kovacs' reagent for the detection of indole. Amer. J. clin. Path. 26, 1373.

GARD, S. (1938). Das Schwärmphänomen in der Salmonella-gruppe und seine praktische Ausnützung. Z. Hyg. InfektKr. 120, 615.

Hugr, R. (1953). The Genus Alcaligenes and Related Organisms. Ph.D. Dissertation, Stritch School of Medicine, Loyola University, pp. 168-170.

Hugh, R. \& Leirson, E. (1953). The taxonomic significance of fermentative versus oxidative metabolism of carbohydrates by various Gram negative bacteria. J. Bact. 66, 24 .

Hugh, R. \& Ryschenkow, E. (1960). An Alcaligenes-like Pseudomonas species. Bact. Proc. p. 78.

Konn, J. (1953). A preliminary report of a new gelatin liquefaction method. J. clin. Path. 6, 249.

KuTSChER, G. W. (1937). Alkaligenes bookeri meningitis. Review of the literature on Gram-negative bacillus meningitis. Arch. Pediat. 54, 610. 
LeIfson, E. (1958). Identification of Pseudomonas, Alcaligenes and related bacteria. Zbl. Bakt. (I. Abt. Orig.), 173, 487.

Leifson, E. (1960). Atlas of Bacterial Flagellation. New York: Academic Press, Inc.

Levine, M. \& Soppeland, L. (1926). Bacteria in creamery wastes. Iowa State College of Agriculture and Mechanic Arts, Ames. Engineering Experiment Station. Bulletin, 7\%, 24, 1 .

LIU, P. V. (1961). Identification of pathogenic pseudomonads by extracellular antigens. J. Bact. 81, 28.

Møller, V. (1954). Diagnostic use of the Braun KCN test within the Enterobacteriaceae. Acta path. microbiol. scand. 34, 115.

Møller, V. (1955). Simplified tests for some amino acid decarboxylases and for the arginine dihydrolase system. Acta path. microbiol. scand. 36, 158.

Moore, B. \& Pickett, M. J. (1960). The Pseudomonas-Achromobacter group. Canad. J. Microbiol. 6, 35.

Pelczar, Jun., M. J. \& Doetsch, R. N. (1949). On the direct fermentation of maltose. Science, 110, 256.

Pollitzer, R. (1959). Cholera, p. 588. Geneva: World Health Organization.

Rhodes, M. E. (1959). The characterization of Pseudomonas fluorescens. J. gen. Microbiol. 21, 221.

Shimwell, J. L., Carr, J. G. \& Rhodes, M. E. (1960). Differentiation of Acetomonas and Pseudomonas. J. gen. Microbiol. 23, 283.

Ulrich, J. A. \& Needham, G. M. (1953). Differentiation of Alcaligenes faecalis from Brucella bronchiseptica by biochemical and nutritional methods. J. Bact. 65, 210.

WeLdiv, J. C. (1927). The colon-typhoid group of bacteria and related forms. Relationships and classification. Iowa St. Coll. J. Sci. 1, 121.

\section{EXPLANATION OF PLATE}

Fig. 1. Pseudomonas maltophilia strain 611 showing a rod with a polar tuft of seven short flagella; $\times 2000$.

Fig. 2. $P$. maltophilia strain 611 showing a rod with a polar tuft of five flagella; $\times 2000$.

Fig. 3. $P$. maltophilia strain 611 showing a rod with a polar tuft of four flagella; $\times 2000$.

Fig. 4. P. maltophilia strain 611 undergoing binary fission with one of the two daughters showing a polar tuft of three flagella; $\times \mathbf{2 0 0 0}$.

Fig. 5. P. maltophilia strain 611 showing a rod with a polar tuft of three flagella; $\times 2000$.

Fig. 6. P. maltophilia strain 611 showing a rod with a polar tuft of two flagella; $\times 2000$.

Fig. 7. P. maltophila strain 611 undergoing binary fission with both daughters showing a polar tuft of two flagella at the distal ends; $\times 2000$.

Fig. 8. P. maltophilia strain 611 showing a rod with a single long polar flagellum; $\times 2000$. 


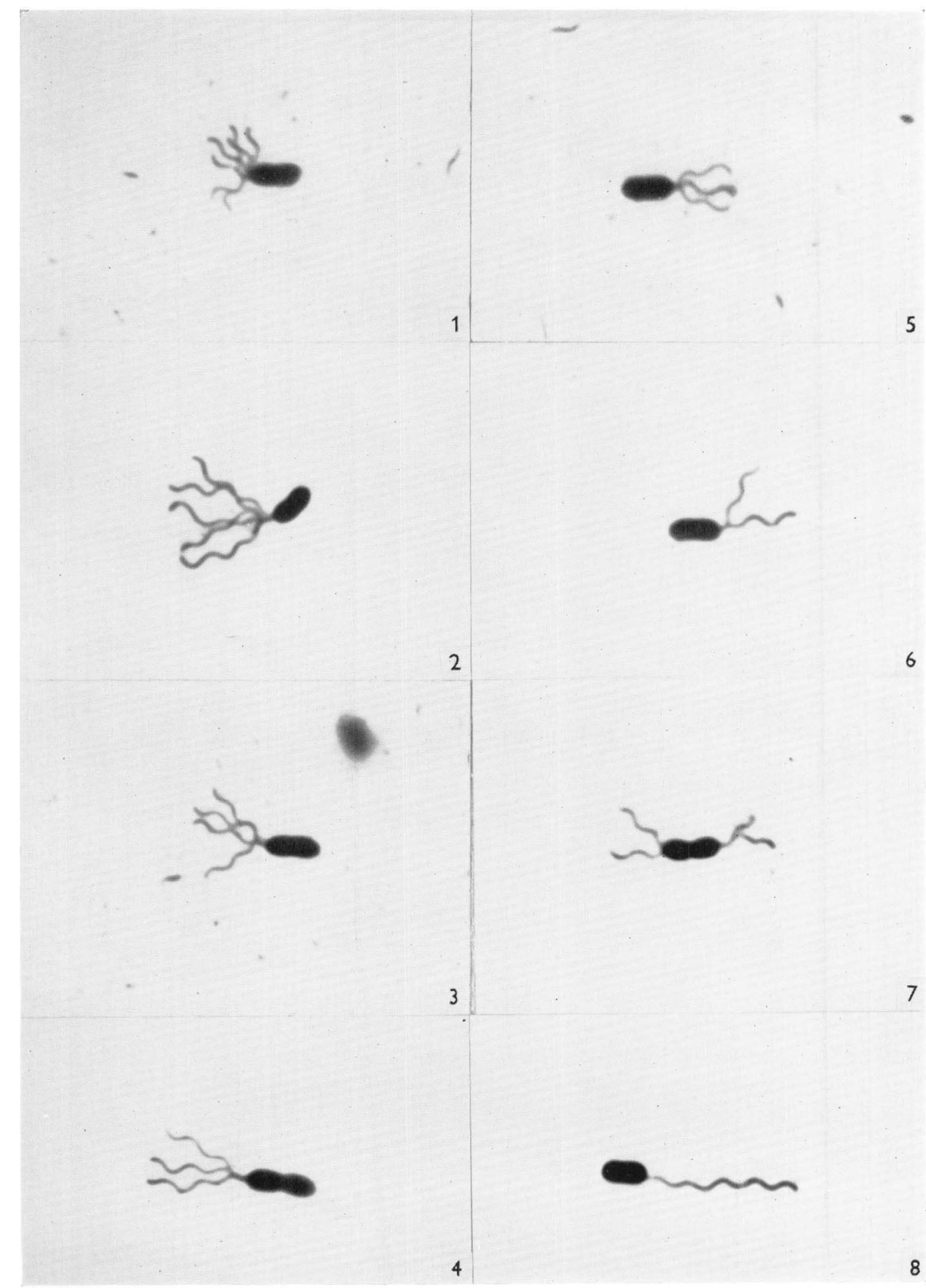

R. HUGH AND E. RYSCHENKOW 